\title{
Avaliação da morfologia e das medidas lineares do canal nasopalatino de pacientes com e sem fissuras labiopalatinas em exames de Tomografia Computadorizada de Feixe Cônico
}

\section{RESUMO}

Os pacientes com fissuras labiopalatinas podem apresentar um comprometimento estético e funcional na região anterior da maxila devido, além da presença da fissura, às ausências dentárias próximas a ela. Um dos reparos anatômicos mais importantes na região anterior da maxila é o canal nasopalatino (CNP). Este canal é localizado na região mediana da face, entre os ossos maxilares, posterior às raízes dos incisivos centrais superiores. Para o sucesso das cirurgias realizadas nessa região, como a colocação de implantes, é necessário o conhecimento prévio da morfologia e localização deste canal. As imagens obtidas com a Tomografia Computadorizada de Feixe Cônico (TCFC) permitem a avaliação tridimensional das estruturas ósseas e dentárias, possibilitando o reconhecimento de estruturas anatômicas e o planejamento cirúrgico com segurança. Assim, os objetivos desse trabalho foram identificar e comparar a morfologia e dimensões do canal nasopalatino de indivíduos com e sem fissuras labiopalatinas por meio de imagens de TCFC e relacionar as alterações encontradas com tipo de fissura e ausências dentárias na região. Foram utilizados 100 exames de TCFC de pacientes com fissuras labiopalatinas do tipo pré-forame e pósforame e 100 exames de TCFC de pacientes sem fissuras labiopalatinas, Obteve-se como resultado que no grupo de pacientes com fissura, os formatos de funil, banana e agulha do CNP foram mais frequentes que no grupo controle. A presença de dois canalículos ou de canalículos em formato de $Y$ no interior do CNP do grupo controle foi mais frequente. $\mathrm{O}$ grupo controle apresentou o forame nasopalatino com menor diâmetro e maior número de aberturas. A presença de fissura labiopalatal apresentou impacto significativo no diâmetro e comprimento do canal nasopalatino. Os pacientes com fissuras apresentaram espessura óssea anterior ao CNP menor que no grupo controle. Pacientes edêntulos apresentaram menor espessura óssea na região do CNP. Este estudo confirma a variabilidade anatômica do CNP em pacientes com fissuras labiopalatinas. Esta constatação reforça a necessidade de um planejamento cirúrgico minucioso da região anterior da maxila, em exames de TCFC, pelo cirurgiãodentista.

Descritores: Tomografia Computadorizada de Feixe Cônico. Fenda Labial. Fissura palatina. Anatomia. Maxila. 